\title{
Difficulties in Treating a Patient with Multiple Cancers in the COVID-19 Pandemic
}

\author{
Ioana Lupușoru', Delia Ciobanu², Manuela Ursaru³, Gheorghiță G Bălan ${ }^{4}$ and Alexandru Grigorovici ${ }^{5^{*}}$ \\ 1Department of General Surgery, "Sfântul Spiridon" Hospital, Iasi, Romania \\ 2Department of Pathology, "Sfântul Spiridon" Hospital, "Grigore T. Popa" University School of Medicine, Iasi, Romania \\ ${ }^{3}$ Department of Radiology, "Sfântul Spiridon" Hospital, "Grigore T. Popa" University School of Medicine, lasi, Romania \\ "Department of Gastroenterology, "Sfântul Spiridon" Hospital, "Grigore T. Popa" University School of Medicine, lasi, Romania \\ ${ }^{5}$ Department of General Surgery, "Sfântul Spiridon" Hospital, "Grigore T. Popa" University School of Medicine, lasi, Romania
}

*Corresponding author: Alexandru Grigorovici, MD Departament of Surgery „Stântul Spiridon” Hospital Bdul. Independenței no 1 lasi, Romania

E-mail: ale.grigorovici@umfiasi.ro

\section{Rezumat}

Dificultăti de tratament pentru un cancer multiplu, complicat în perioada pandemiei cu COVID-19

În contextul pandemic actual, pacienții cu cancer prezintă un risc adițional, iar protocoalele de tratament sunt în continuă modificare. Vă prezentăm un pacient în vârsta de 62 de ani, care pe parcusul a 4 ani dezvoltă 3 tipuri de cancer şi care se prezintă în regim de urgență pentru hematemeză, melenă şi dureri abdominale. Din antecedentele patologice ştim că fusese operat în 2017 pentru o formațiune tumorală scapulară stângă (carcinom bazocelular). Examenul clinic actual descoperă altă formațiune scapulară dreaptă (melanom malign), iar hematemeza provine de la o formațiune tumorală gastrică (carcinom scuamocelular). Infectiia cu SARS-CoV2 schimbă regulile de tratament într-un asemenea caz. Astfel, pacientul este operat pentru formatiunea scapulară dreaptă, gastrectomia fiind amânată datorită leziunilor pulmonare date de SARS-CoV2. În final pacientul beneficiază de tratment chirurgical pentru formațiunea gastrică în condițiile negativării testului RT-PCR.

Cuvinte cheie: COVID-19, carcinom bazocelular, carcinom scuamos, melanom malign

\section{Abstract}

In the actual pandemic context, cancer patients are at additional 
risk, and protocols are always changing. We present the case of a 62-year-old patient who develops three types of cancer over four years and who was admitted to the hospital in the Emergency Room for hematemesis, melena, and abdominal pain. We know from the pathological antecedents that he was operated in 2017 for a left scapular tumour (basal cell carcinoma). The current clinical examination reveals another right scapular tumour (malignant melanoma), and the hematemesis comes from a gastro-esophageal junction tumour (squamous cell carcinoma). SARS CoV2 infection changes the rules of treatment in such a case. Thus, the patient is operated for the right scapular tumour, the gastrectomy being delayed due to the lung lesions given by SARS CoV2. Finally, the patient undergoes surgery for the gastric tumour, the RT-PCR retest being negative.

Key words: COVID-19, basal cell carcinoma, malignant melanoma, squamous cell carcinoma

\section{Introduction}

Starting with the end of 2019 , the world has been facing the pandemic caused by the SARS-CoV2 virus, and since then, numerous studies quoting various treatment options are still continually changing. SARS-COV-2 has airborne transmission by direct exposure or by direct contact with surfaces contaminated with viral particles (1).

The Society of Surgical Oncology recommends that all cancer patients requiring surgery should be tested before surgery (2). The test is necessary because the asymptomatic patients infected with SARS-CoV2, who require oncological surgery, experience a more difficult evolution, including a higher mortality rate (3).

Basal cell carcinoma is the most common skin cancer. In the United States, 4.3 million people are diagnosed every year with this disease. The second place is occupied by squamous cell carcinoma, being diagnosed annually at 1 million people (4).

During 2017, in the United States, there were 85,686 new malignant skin melanoma cases and 80,56 secondary deaths. An estimated 196,060 cases were diagnosed with melanoma in 2020. In the same year, 2017, there were 24,286 new gastric cancer cases and 11,158 deaths.

\section{Case Report}

The paper aims to present the evolution of a patient with multiple malignant tumours during the COVID-19 pandemic. A 62-year-old urban male patient, with history of hepatitis virus $\mathrm{C}$ infection, has been surgically managed in 2017 for a left scapular tumour that turned out to be a localized metatypical basal cell carcinoma (Figs. 1, 2).

On May 29, 2020, the patient arrives at the
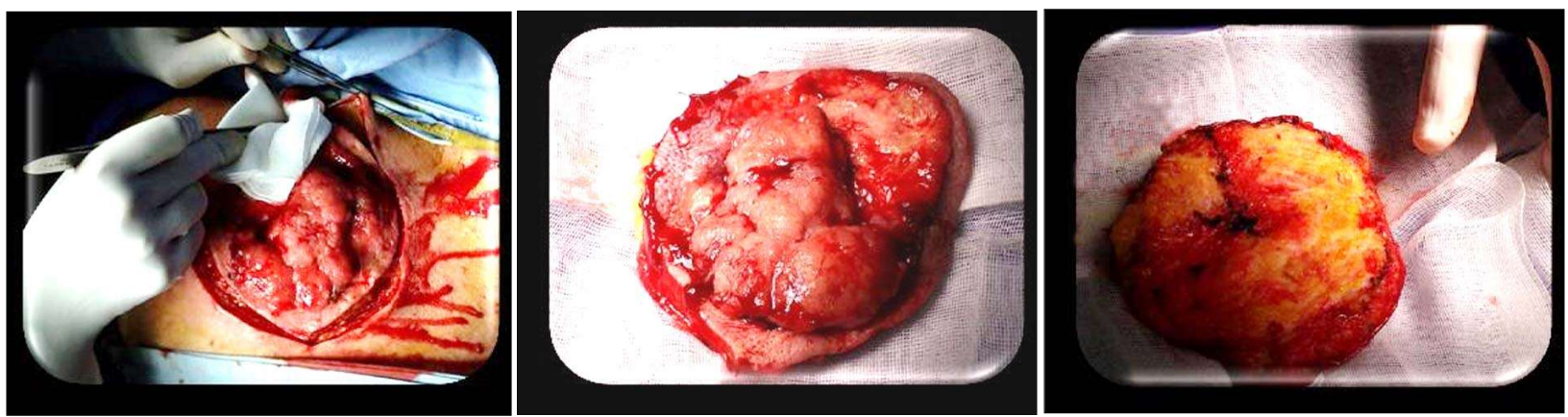

Figure 1. Intraoperative images: tumour about $10 \mathrm{~cm}$ in diameter, well delimited with ulcerated areas; the excision includes resection margins in healthy tissue, both on the surface and in-depth 

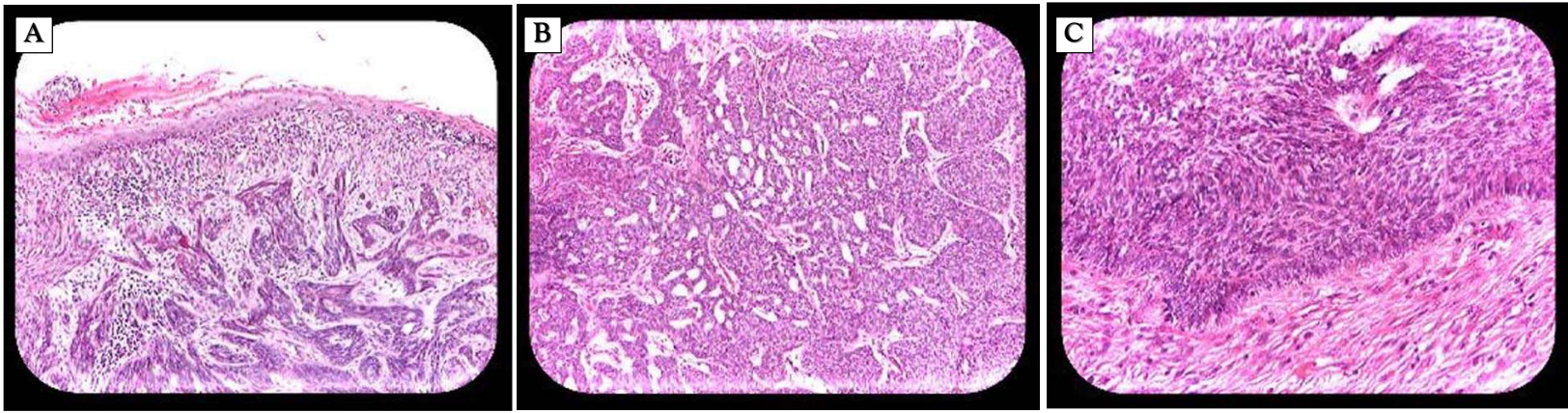

Figure 2. (A) Tumor proliferation has 2 components: one is consisting of basaloid tumour cells and the other of squamous tumour cells with focal keratinization. A desmoplastic stroma is noticed, together with an abundant peritumoral inflammatory infiltrate, predominantly lympho-plasmacytic and a foreign giant cell reaction (keratin). Perineural infiltration and absence of vascular invasion are found; (B) adenoid and solid areas; (C) cells disposed in the peripheral palisade and disordered cells in the centre of the island

emergency room with diffuse abdominal pain with maximum intensity in the epigastrium accompanied by hematemesis and melena, significant secondary anaemia (Hemoglobin = $7.3 \mathrm{~g} / \mathrm{dl}$; Hematocrit $=22.2 \%$; Platelets $=154$

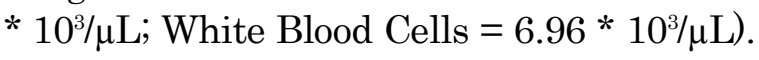

The patient's clinical examination describes a supple depressed abdomen, mobile with breathing, painful in the epigastrium on deep palpation. The digital rectal examination reveals melena. At the right scapular level, an ulcerated tumour formation of about $4 / 5 \mathrm{~cm}$ pedicled was discovered (Fig. 3).

The abdominal computed tomography (CT) scan reveals an expansive gastric tumour suggestive of malignancy, stage $\mathrm{T} 4 \mathrm{~N} 3 \mathrm{Mx}$ (Fig. D).
Figure 3. Right scapular formation

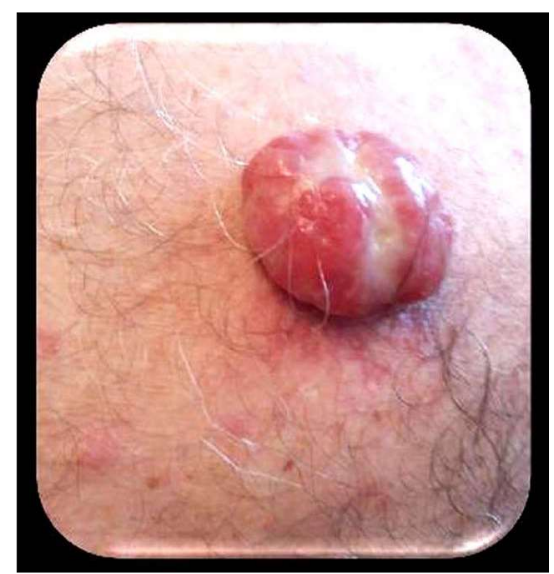

The hospital protocol requires a chest CT scan to highlight any lesions that may suspect SARS-CoV2 infection in the actual
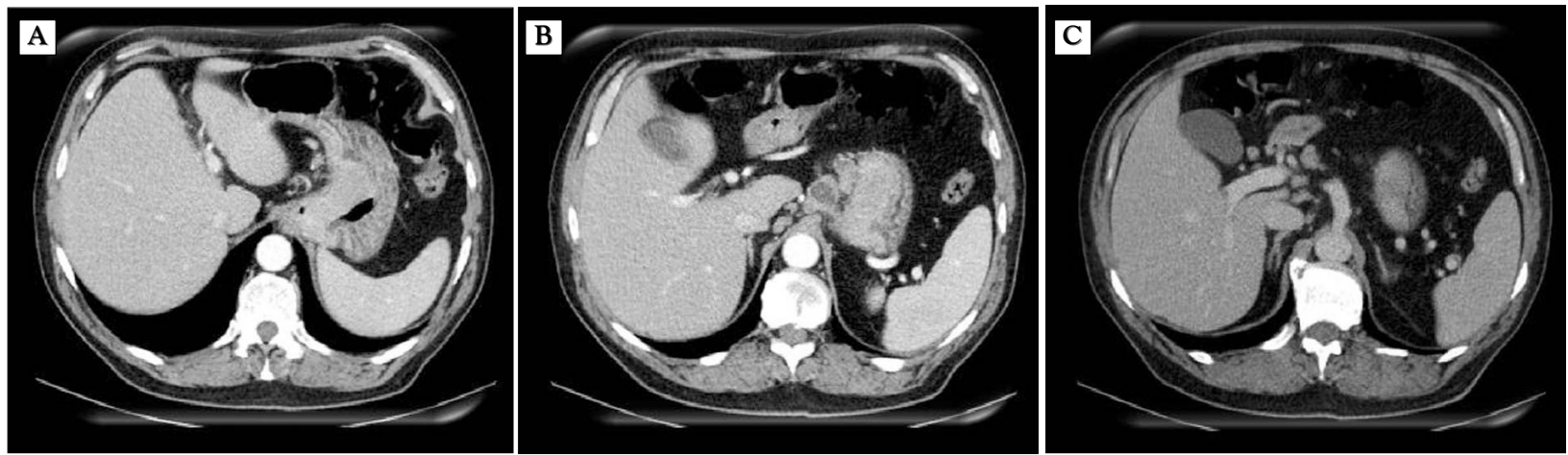

Figure 4. (A) gastric parietal thickening at the level of the fornix extended on the small curvature; lymphadenopathy on the small gastric curvature; (B) Nodular formations with central necrosis located on the small gastric curvature; thickened gastric wall on the small curvature; (C) Celiac lymphadenopathy and hepatic hilum 

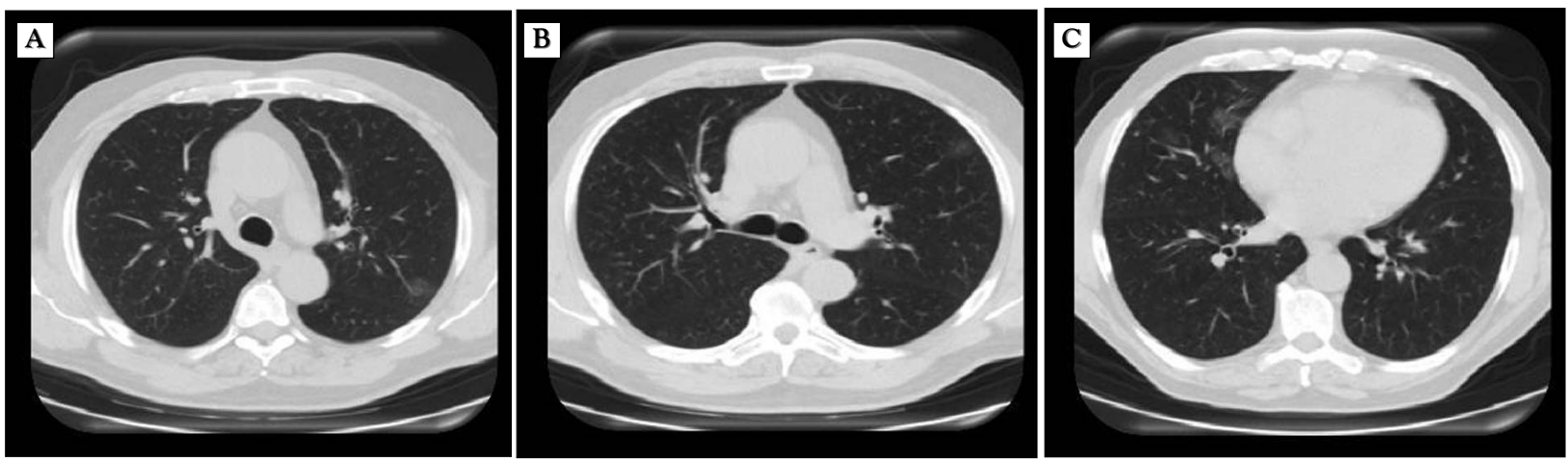

Figure 5. (A) "Ground-glass" nodular opacities located subpleural of the left upper lobe (suggestive for pneumonia COVID-19);

(B) "Ground-glass" nodular opacities located subpleural of the left upper lobe (suggestive for pneumonia COVID-19);

(C) "Ground-glass" nodular opacities appearance, located subpleural of the middle lobe (suggestive for pneumonia COVID - 19)

epidemiological context (Fig. 5).

CT images raise the suspicion of COVID-19 pneumonia, which is why RT-PCR is collected. The result is positive.

Although the hospital is a non-COVID facility, the patient's emergency status requires his hospitalization with the diagnosis of hemorrhagic mallignancy. The patient is admitted to the surgical department, isolated and conservative treatment is instituted with hemostatics, blood transfusions, the surgery being delayed due to the patient's general condition (anaemia and COVID 19 pneumonia).

On the recommendation of the infectious diseases department, treatment with Kaletra is instituted. Under conservative treatment (hemostatics), for five days, the bleeding is stopped, and the anaemia is corrected. The second RT-PCR test (02.06.2020) remains positive, which is why the patient is transferred, according to the COVID-19 protocol, to the Infectious Diseases Hospital.

The patient receives treatment with Kaletra tablets IV/day for 10 days and Plaquenil tablets IV/day for 10 days. During admission, the patient does not bleed. After the end of the treatment and two negative RT-PCR tests (18.06.2020 and 19.06.2020), the patient is redirected to the surgical department for specific treatment. The epidemiological protocol says the patient needs to be retested RT-PCR on 20.06.2020 with a negative result.

The patient undergoes upper digestive endoscopy with biopsy sampling from the gastro-esophageal junction tumour (Fig. 6).

The anatomopathological result of the sampled biopsy describes a formation with high-grade epithelial dysplasia (in situ neoplasia) on the squamous epithelial slope (Fig. 7). According to the epidemiological protocol, the patient is retested on 23.06. 2020, the result being positive.

The RT-PCR tests are repeated on 26.06.2020 and 28.06.2020 (Fig. 9), both being positive. The ulceration at the level of the scapular tumour erodes a blood vessel and provokes heavy bleeding, thus a surgical procedure under local anaesthesia is needed. The patient no longer shows symptoms specific to COVID-19 infection, and on 29.06. 2020 , the scapular tumour is excised.

The anatomopathological diagnosis is acromic nodular malignant melanoma pT4bNxL0V0Pn0R0 (Fig. 8).

Considering the patient's neoplastic history of mallignancy: metatypical basal cell carcinoma (operated 2017), gastro-esophageal junction squamous cell carcinoma, and malignant melanoma, an oncological evaluation is required for neoadjuvant treatment. The oncology board schedules the patient for evaluation and neoadjuvant treatment in 2 months. The patient returns to the emergency unit on 09.07.2020 for hematemesis. Hemostatic and hydro electrolytic treatment is started immediately, erythrocyte masses are established. Furthermore, he is retested for SARS CoV2, the result being negative. We 

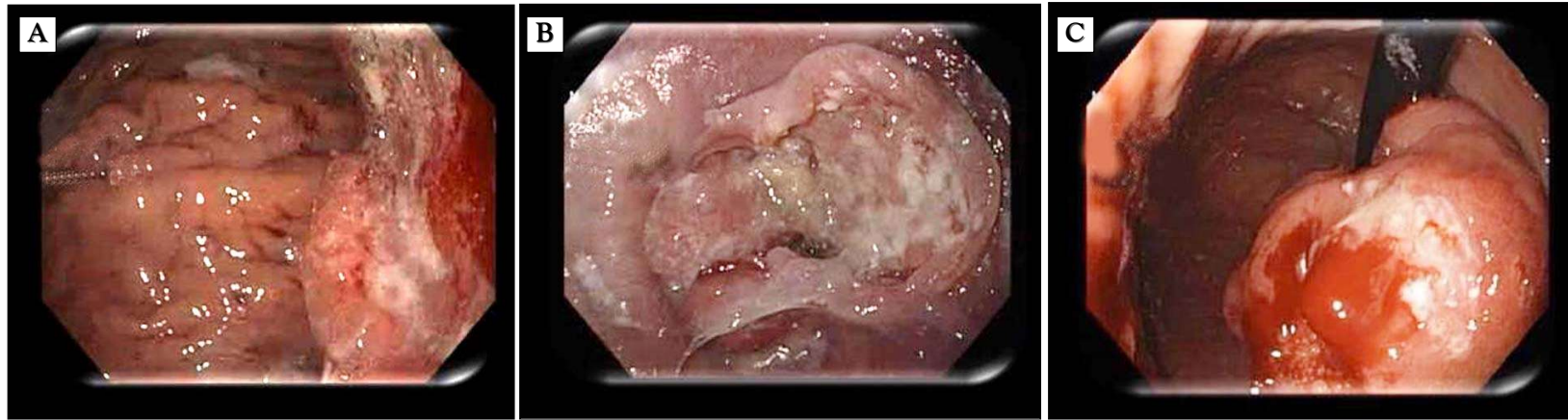

Figure 6. (A) Endoscopic aspect with a regular diagnostic gastroscope (Exera II, Olympus, Tokyo, Japan) advanced to $5 \mathrm{~cm}$ above the gastro-esophageal junction: circumferential invasion of the cardia by a mixed Paris Is-Ila-III lesion with a bulky amorphous pattern ( 9 o'clock) and a deep infiltrating ulcerous pattern (3 o'clock) with necrotic debris, typical for malignancy; (B) Endoscopic aspect with a regular diagnostic gastroscope (Exera II, Olympus, Tokyo, Japan) advanced below the gastroesophageal junction in the upper stomach: same lesion with an ulcerative-infiltrative Paris Ila-III pattern ( 3 o'clock) invading the lesser curvature of the gastric corpus. The same amorphous pattern of the elevated lla component and the deep central ulcer with necrotic debris can be seen and are suggestive for deep invasion; (C) Endoscopic aspect with a regular diagnostic gastroscope (Exera II, Olympus, Tokyo, Japan) advanced in the lower stomach in a retroflex position: a bulky Paris Is mass component on the lesser curvature of the stomach down to the lower corpus, with active oozing bleeding and some debris. Despite active bleeding, biopsies were taken, and the hemostasis has been achieved by pure alcohol injection.
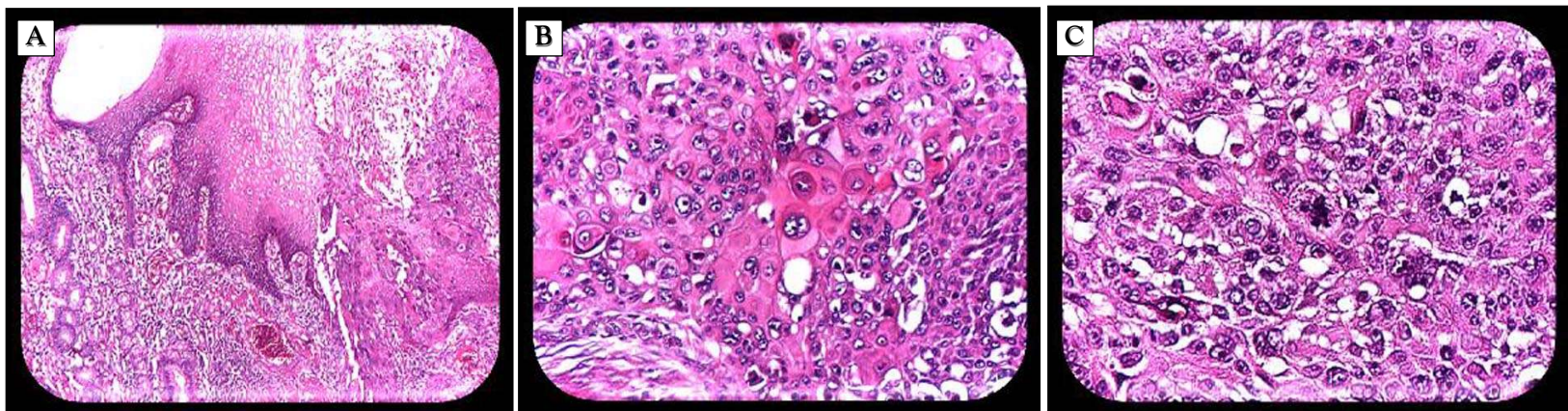

Figure 7. (A) Moderately differentiated squamous cell carcinoma. The presence of an eso-gastric passage with high-grade epithelial dysplasia is noted; (B) Proliferation has a vaguely papillary architecture, and cell pleomorphism is moderate; (C) Atypical mitosis.
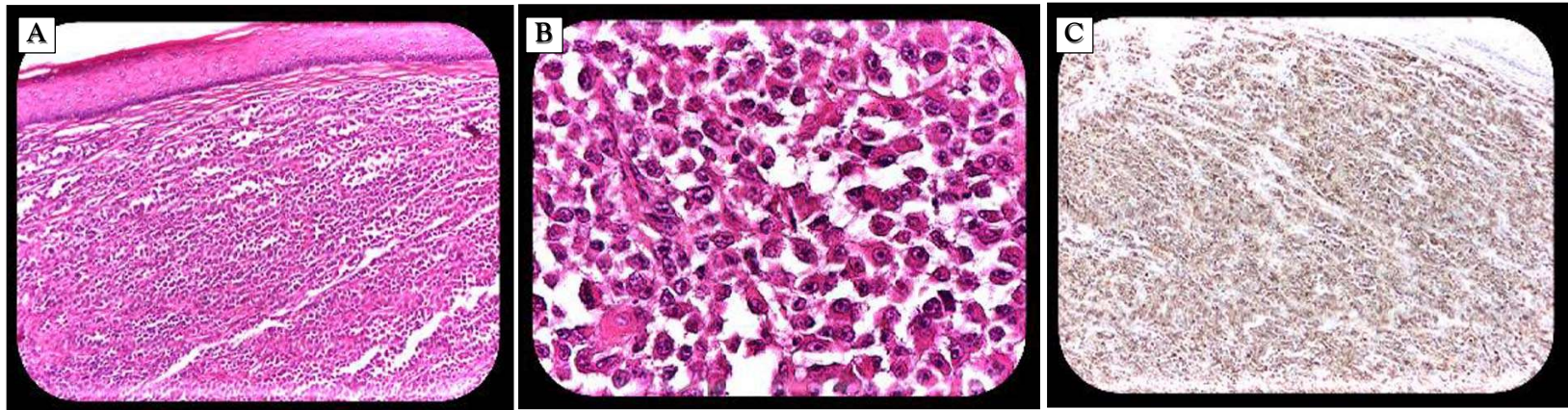

Figure 8. (A) Nodular melanoma with epithelioid cells; (B) Epithelioid cells with eosinophilic macronucleus; (C) positive intratumoral HMB45 (immunohistochemistry) 


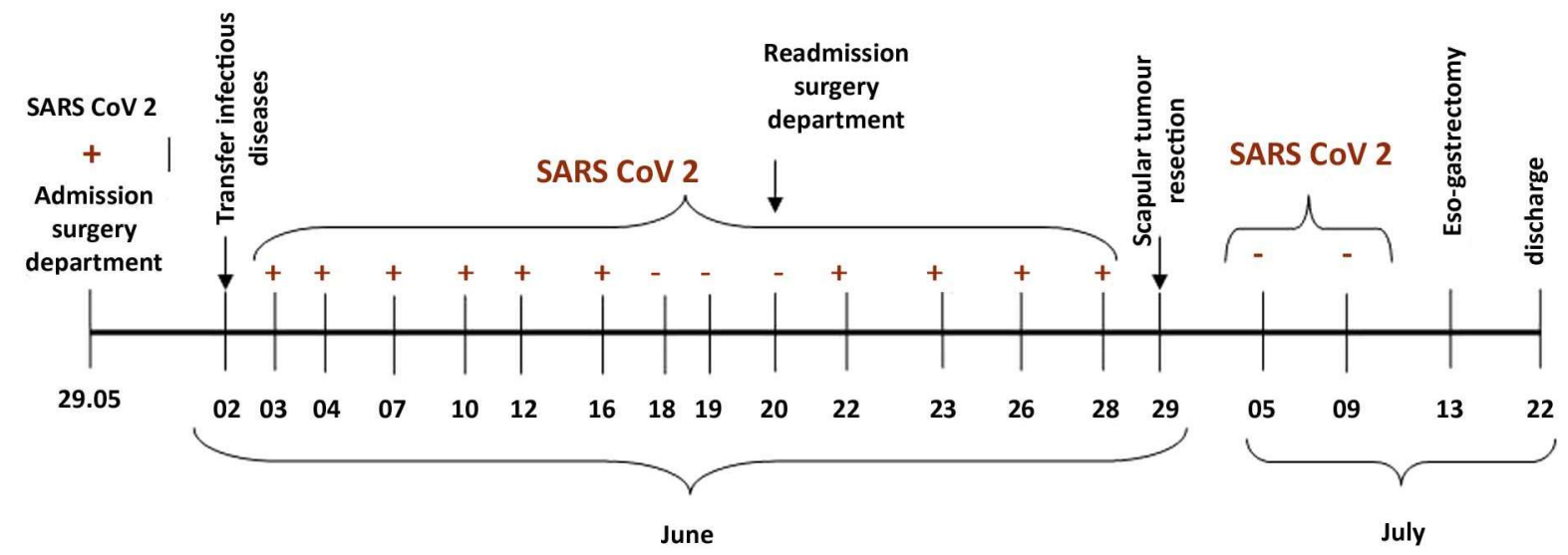

Figure 9. The evolution of the patient from the admission to the discharge

decide to give up neoadjuvant treatment due to repetitive upper digestive haemorrhage and, on 13.07.2020, the patient undergoes surgery: the surgery team explored the abdomen by laparotomy, they removed the adhesions followed by total eso-gastrectomy with an intrathoracic, transhiatal Roux-en-Y eso-jejunal anastomosis. In the end, the surgeons drained the abdominal cavity with three tubes.

The pathological diagnosis of the resected piece is Moderately differentiated squamous cell carcinoma NOS pT2N3 - G2L1V1Pn1 ENE + . The postoperative evolution is simple with the resumption of digestive tolerance and intestinal transit, which is why the patient is discharged on 22.07.2020, at nine days after surgery.

\section{Discussion}

We are facing a patient with multiple types of cancer and SARS CoV2 infection, in a pandemic period with social and medical restrictions. The "State of Emergency" in Romania was established on March 16, 2020, for 30 days, and it was followed by a "State of alert" still in force in this moment.

The right scapular tumour (malignant melanoma) was scheduled for surgery in March but was postponed due to the state of emergency. A study made in China showed that cancer patients have an increased risk of
SARS-CoV2 infection compared to those without cancer. Also, cancer patients have been shown to have poorer outcomes, alerting physicians about a much faster health deterioration (5).

Specific and detailed treatment recommendations for tumour types and specific treatments were not widely available. However, ESMO has issued more specific recommendations for some types of gastrointestinal cancer (colorectal, oesophagal, and pancreatic) and proposed treatments based on priority levels; however, direct treatment recommendations for each tumour stage are not provided (6).

Upper gastrointestinal haemorrhage associated with COVID-19 infection (with pneumonia) raised difficult diagnosis and treatment problems when very detailed protocols were not established for these patients. Anaemia and hypoproteinemia have been a significant consequence of nutritional impairment in cancer patients, which may adversely affect immunocompetence and increase susceptibility to respiratory pathogens (7). For this particular case, symptomatic treatment with hemostatics was administered, which managed to stop the bleeding and transfer the patient to the Infectious Diseases Hospital where the administered treatment managed to remit the pulmonary phenomena given by SARS-CoV2. At first, only the thoraco-abdominal $\mathrm{CT}$ raised the 
suspicion of an eso-cardio- tuberosity tumour, for which a possible surgical approach could have involved a thoracotomy. In a patient with COVID-19 pneumonia with respiratory failure, the prognosis would have been extremely poor.

Miyashita et al. (8) published an article analyzing the risk of intubation in patients with COVID-19 with cancer vs without cancer by age groups and found a significantly increased risk of intubation in cancer patients aged $66-80$ years. Also, cancer patients under the age of 50 had a significantly higher mortality rate.

The same still unclear protocol made us hesitate the surgical approach per primam, due to the positive and negative PCR tests even after three weeks. We managed to perform an upper digestive endoscopy after the retransfer from the Infectious Diseases Hospital, that showed us the existence of a tumour invasion only at cardio-tuberosity level, although the anatomopathological result of the biopsy showed the existence of squamous cell carcinoma. For cancer patients, delaying surgery has the real potential to increase the metastatic disease, with patients' tumours ranging from being curable (with almost average life expectancy) to being incurable (limited life expectancy) (9).

The oncology board decided to perform a neoadjuvant treatment if the haemorrhage stopped (during the four weeks of hospitalization, the patient did not externalize hematemesis and/or melena). While waiting for the neo-adjuvant treatment, the patient externalizes, two days after discharge, hematemesis and abundant melena, which makes us decide the surgical intervention per primam, even with the risk of having a hybrid thoraco-abdominal approach (respiratory phenomena were remitted almost completely). Performing total eso-gastrectomy with transhiatal eso-jejunal oanastomosis had a "benign" evolution. The anatomo-pathological surprise resulted from the right scapular formation with a much more questionable prognosis (nodular malignant melanoma pT4bNxL0V0Pn0R0). Currently, three months after surgery, the patient is undertaking adjuvant treatment for the multiple tumours.

\section{Conclusion}

This case proves that doctors treat patients and not the disease, and the protocols are sometimes outdated by the context of the pandemic. The patient with multiple types of cancer, thus having a flawed immune system associated with SARS CoV2 infection, an anaemic syndrome caused by the bleeding at the level of the scapular and the cardiotuberosity tumour, which required transfusions, manages to survive these repeated interventions. The prognosis is questionable in the long term, mainly due to malignant melanoma.

\section{Conflict of Interests}

The authors declare no conflicts of interests.

\section{References}

1. Tomulescu V, Surlin V, Scripcariu V, Bintintan V, Duta C, Calu V, et al. Colorectal Surgery in Romania during the COVID-19 Pandemic. Recommendations of the Romanian Society of Coloproctology (SRCP) and the Romanian Association for Endoscopic Surgery (ARCE) Chirurgia (Bucur). 2020;115(2):129-137.

2. Society of Surgical Oncology Cancer Surgeries in the Time of COVID-19: A Message from the SSO President and President-Elect, 23 March 2020. (Online]. Available: https://www.surgonc.org/ wpcontent/uploads/2020/03/COVID-19-Letter-to-Members.pdf.

3. Lei S, Jiang F, and Su W, Chen C, Chen J, Mei W, et al. Clinical characteristics and outcomes of patients undergoing surgeries during the incubation period of COVID-19 infection. EClinicalMedicine. 2020;21:100331.

4. Skin Cancer Facts \& Statistics, aprilie 2020. (Online]. Available: https:// www.skincancer.org/skincancer-information/skin-cancer-facts/.

5. Liang W, Guan W, Chen R, Wang W, Li J, Xu K, et al. Cancer patients in SARS-CoV-2 infection: a nationwide analysis in China. Lancet Oncol. 2020;21(3):335-337.

6. Riechelmann RP, Peixoto R, Fernandes G, Weschenfelder RF, Prolla G, Rocha Filho D, et al. Evidence-based recommendations for gastrointestinal cancers during the COVID-19 pandemic by the Brazilian Gastrointestinal Tumours Group. Ecancermedicalscience. 2020;14:1048.

7. Zhang L, Zhu F, Xie L, Wang C, Wang J, Chen R, et al. Clinical characteristics of COVID-19-infected cancer patients: a retrospective case study in three hospitals within Wuhan, China. Ann Oncol. 2020;31(7):894-901.

8. Miyashita H, Mikami T, Chopra N, Yamada T, Chernyavsky S, Rizk $D$, et al. Do patients with cancer have a poorer prognosis of COVID19? An experience in New York City. Ann Oncol. 2020;31(8): 1088-1089.

9. Kutikov A, Weinberg DS, Edelman MJ, Horwitz EM, Uzzo RG, Fisher RI. A war on two fronts: cancer care in the time of COVID19. Ann Intern Med. 2020;172(11):756-758. 